\section{СПИСОК ЛІТЕРАТУРИ}

1. Бараш Ю. С. Управління залізничним транспортом країни: Монографія. -2-ге вид. переробл. і допов. - Д.: Вид-во Дніпропетр нац. ун-ту залізн. трансп. ім. акад. В. Лазаряна, 2006. $264 \mathrm{c}$.

2. Бараш Ю. С. Види нових організаційних структур 3 управління залізничним транспортом в Україні та основні принципи їх побудови // Залізничний трансп. України. - 2006. - № 5, - С. 49-53.

3. Булгакова Ю. В. Концептуальный подход к реформированию ремонтной базы для грузовых вагонов в современных рыночных условиях / Ю. С. Бараш, Ю. В. Булгакова // Наук. вісн. Нац. гірничого ун-ту. - Д. : Вид-во НГУ, 2013. - № 3. - C. 126-133.

$\begin{array}{lll}\text { 4. Гудкова } & \text { В. П. Методологія }\end{array}$ забезпечення ефективної діяльності підприємств сфери пасажироперевезень: Монографія / В. П. Гудкова. - К.: ДЕТУТ, 2013. - 290 с.

5. Дикань В. Л. Удосконалення організаційної структури залізничного комплексу України в сучасних умовах / В. Л.Дикань, М. I. Данько, М. В. Кондратюк // Монограія. Харків: УкрДАЗТ, 2010. - 190 с.

6. Естіваль Ж.-П. Організаційні моделі залізниці: національні критерії побудови // Залізничний трансп. України. - 2005. - № 1. - С. 68-71.

7. Ейтутіс Г.Д. Стратегія реформування залізниць України на основі регіоналізації транспортного обслуговування: [Дисертація на здобуття наукового ступеня доктора економічних наук], Київ, 2010p.
8. Петренко Е.А. Реформирование железнодорожного транспорта Украины: теория, проблемы, пути решения: моногр./ Е.А.Петренко; НАН Украины, Ин-т экономики пром-сти. Донецк, 2011. - 358 с.

9. Петренко Е.А. Состояние и перспективы развития железнодорожного транспорта Украины в условиях проводимой реформы / Е.А. Петренко// Бюллетень ОСЖД. Варшава. - 2009. - № 4-5 (306-307) - С. 23-29.

10.Петренко Е. Ролята на дьржавата в дейността и реформирането на жп транспорта / Е. Петренко// Железопьтен транспорт (Railway transport magazine). - България, София. - 2010. №1. - C. $40-41$.

11.Пшінько О. М. Управління вантажними вагонами компаній-операторів в умовах реформування залізничного транспорту / О. М.Пшінько, Ю. С. Бараш, Л. В. Марценюк // Монографія / Дніпропетр. нац. ун-т. залізн. трансп. ім.. акад.. В. Лазаря на. - Дніпропетровськ, 2015. $147 \mathrm{c}$.

12.Чаркіна Т. Ю. Принципи формування інфраструктурної складової для побудови пасажирських залізничних тарифів / Т. Ю. Чаркіна // Зб. наук. праць Дніпропетр. нац. ун-ту залізн. трансп. ім. акад. В. Лазаряна. «Проблеми економіки транспорту». - Д.: Вид-во Дніпропетр. нац. ун-ту залізн. транспорт. ім. акад. В. Лазаряна, 2015. - Вип. 10. - С. 59-64

13.Юхновський I. P. Транспортний комплекс України. Залізничний транспорт: Проблеми та перспективи. За ред. I. Р. Юхновського. - К.: ФАДА ЛТД, 2006. - 288 с.

14.Gudkova V. P. Diagnostics of competitive ability by retroactive effect method / V. P. Gudkova // Nauka I Studia. - NR 2 (72). - 2013. - P. 31-36.

Експерт редакційної колегії к.е.н., дочент УкрДУЗТ Слагін Ю.В.

УДК 338.47:656.2

\title{
УДОСКОНАЛЕННЯ МЕТОДИКИ ОЦІНКИ ЕФЕКТИВНОСТІ ЕКСПЛУАТАЦЇ̈ ЛОКОМОТИВНОГО ПАРКУ ПАТ «УКРЗАЛІЗНИЦЯ»
}

\author{
Зіць О.Є., аспірант (ДЕТУТ)
}

На основі матричного підходу у статті здійснено порівняльний аналіз ефективності використання локомотивів за 2013 та 2014 роки.

3 метою усунення подвійного обліку або виключення впливу якісних показників на ефективність використання локомотивів визначені 4 вертикальних ієрархічних рівня, а також 
здійснено горизонтальний розподіл показників, щуо характеризують якість експлуатації локомотивів за потужністю, часом і пробігом.

Обгрунтовано, щуо найвищим 1-им вертикальним рівнем є показник продуктивності локомотива, який інтегрує всі показники, щуо характеризують ефективність експлуатації локомотивного парку.

Ключові слова: якісні показники використання локомотивів, матричний підхі, вертикальні ісрархічні рівні, продуктивність локомотива, ефективність.

\title{
СОВЕРШЕНСТВОВАНИЕ МЕТОДИКИ ОЦЕНКИ ЭФФЕКТИВНОСТИ ЭКСПЛУАТАЦИИ ЛОКОМОТИВНОГО ПАРКА ПАО“УКЗАЛИЗНЫЦЯ”
}

\author{
Зиц A.E., acnipaнm (ГЭТУТ)
}

На основании матричного подхода в статье осущчествлен сравнительный анализ эффективности использования локомотивов за 2013 ma 2014 годы.

С иелью устранения двойного учета или исключения влияния качественных показателей на эффективность использования локомотивов определены 4 вертикальных иерархических уровня, а также произведено горизонтальное распределение показателей, которые характеризуют качество эксплуатации локомотивов за мощзностью, временем и пробегом.

Обосновано, что самым высоким 1-ылм вертикальным уровнем является показатель производительность локомотива, который интегрирует все показатели, характеризирующие эффективность эксплуатации локомотивного парка.

Ключевые слова: качественные показатели использования локомотивов, матричный подход, вертикальные иерархические уровни, производительность локомотива, еффективность.

\section{LOCOMOTIVE FLEET OPERATION EFFICIENCY ASSESSMENT METHODS IMPROVEMENT JSC "UKRZALIZNYTSIA"}

\section{Zits O.E., postgraduate ( State Economy and Technology University of Transport)}

Based on a matrix approach the article performs a comparative analysis of the efficiency of the use of locomotives for 2013 and 2014 years.

Aimed to avoid double accounting or exclude the effect of qualitative indicators on the efficiency of the use of locomotives, the 4 vertical hierarchical levels are specified as well as a horizontal distribution is performed for the indicators characterizing the quality of the operation of locomotives by power, time and run.

The scheme depends indicators of cars determine the appropriate calculation algorithm, which enables conducting systematic and objective assessment of the efficiency of inventory park of locomotive.

It is substantiated that the highest, 1st vertical level is a locomotive productivity indicator integrating all indicators characterizing the efficiency of the operation of the locomotive fleet.

In order to illustrate the proposed method essentially presenting the article analyzes the impact of quality indicators of railways of Ukraine on performance of locomotive.

Using the given methods of the assessment of the efficiency of the operation of the locomotive fleet assists in objective determining the key performance indicators (KPI) being a main indicator of labor motivation.

Keywords: locomotive use qualitative indicators, matrix approach, vertical hierarchical levels, locomotive productivity, efficiency.

Постановка проблеми. Ефективний розвиток залізничного транспорту, що складає основу транспортної системи країни, $\epsilon$ необхідною умовою забезпечення економічного і соціального зростання та обороноздатності держави. Реалізація Державної цільової програми реформування залізничного транспорту на 2010 2019 роки висуває конкретні вимоги до організації всіх видів економічної діяльності щодо раціонального використання основних 
засобів, в першу чергу локомотивного парку. Для аналізу ефективності експлуатації i магістральних локомотивів на залізницях функціонує система показників, які характеризують роботу рухомого складу за потужністю, часом i пробігом. Але слід зазначити, що існуючий порядок визначення впливу конкретного показника $є$ недосконалим. Багато факторів, які впливають на результат використання локомотивного парку не враховуються, а якщо враховуються, то припускаються випадки подвійного обліку.

Саме тому виникає необхідність у розробці такої методики оцінки ефективності експлуатації локомотивного парку, яка б була зрозумілою та об'єктивною.

Аналіз останніх досліджень. Серед закордонних дослідників ефективності i управління експлуатаційною діяльністю залізниць в своїх працях розглядали Галабурда В.Г. [8], Луніна Т.А. [5], Мачерет Д.А. [9], Парментер Д. [10], Піерантоніо Д. [11] та інші.

Ефективність використання рухомого складу достатньо широко висвітлені в роботах вітчизняних дослідників Ейтутіса Г.Д. [2], Кулаєва Ю.Ф. [4], Макаренка М.В. [6], Пасічника B.I. [7] та інших. Але автори розглядають деякі аспекти цієї складної проблеми.

Відсутність системного та об'єктивного аналізу ефективності експлуатації локомотивного парку в умовах реформування залізниць країни обумовлює мету та завдання цієї публікації.

Метою цієї публікації $\epsilon$ проведення системного дослідження впливу якісних показників використання локомотивного парку на продуктивність локомотива за 2013 та 2014 роки.

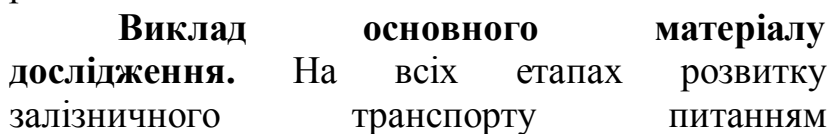
вдосконалення експлуатації основних фондів надавалось першочергове значення, оскільки кінцеві результати залізниць залежать, в першу чергу, від якості використання рухомого складу. Значна роль в цьому належить оперативному управлінню локомотивним парком через низку показників [10, 11].

Існуюча методика визначення впливу конкретного показника на кінцевий результат $€$ недосконалою, багато факторів не враховуються, а якщо враховуються, то припускаються випадки подвійного обліку $[5,8,9]$.

3 метою усунення зазначених недоліків пропонується здійснювати оцінку ефективності експлуатації локомотивного парка на основі матричного підходу, суть якого полягає у розподілі якісних показників, як на горизонталі (використання за потужністю та часом i пробігом), так і по вертикалі, де передбачені ієрархічний (від 1 до 4 рівнів) розподіл показників (рис. 1) [4-7]

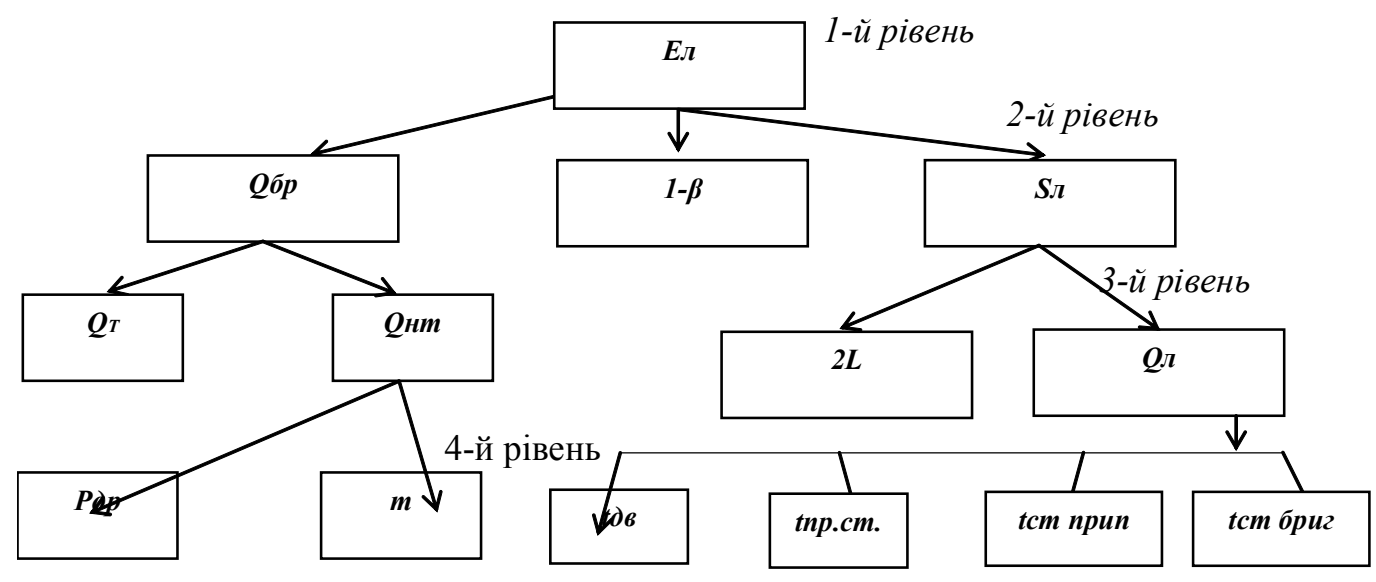

Рис. 1. Залежність показників використання локомотивного парку

$\boldsymbol{E} \boldsymbol{b}$ - продуктивність локомотива; $\boldsymbol{Q} \boldsymbol{\boldsymbol { p }} \boldsymbol{p}$ - вага поїзда брутто; $\boldsymbol{Q} \boldsymbol{m}$ - вага тари, $\boldsymbol{Q}_{\boldsymbol{m} \boldsymbol{m}}-$ вага поїзда нетто; $\boldsymbol{P}_{\boldsymbol{\prime}}-$ динамічне навантаження вагонів робочого парку; $\boldsymbol{m}$ - склад поїзда; $\boldsymbol{S}_{\boldsymbol{l}}-$ показник середньодобового пробігу; $\boldsymbol{t} \boldsymbol{\partial} \boldsymbol{\varepsilon}$ - час локомотива у русі; $\boldsymbol{t n p . c m}$ - час перебування на проміжних станціях; tcm npun - час на станції приписки; $\boldsymbol{t c m}$ бриг - час зміни локомотивних бригад; $\boldsymbol{\beta}$ - частка допоміжного пробігу локомотива від пробігу в голові поїзда, $\% ; \boldsymbol{L}$ - відстань у русі. 
Отже, згідно рис. 1 та табл.. 1 проведено локомотивного парку за 2013 і 2014 pp. порівняльний аналіз ефективності використання

Таблиця 1

\begin{tabular}{|c|c|c|c|c|c|c|c|c|c|c|c|c|}
\hline \multicolumn{13}{|c|}{$\begin{array}{r}\text { Показники використання локомотивного парку } \\
\text { Найменування показника }\end{array}$} \\
\hline$\stackrel{5}{2}$ & 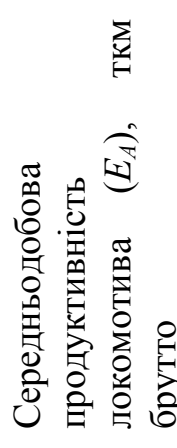 & 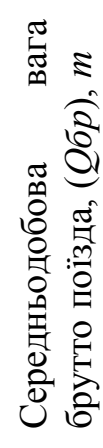 & 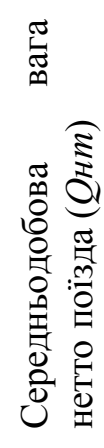 & 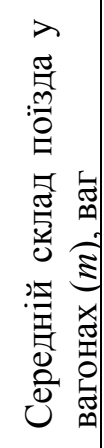 & 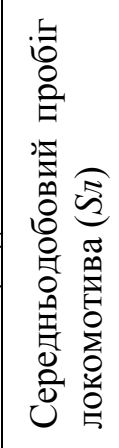 & 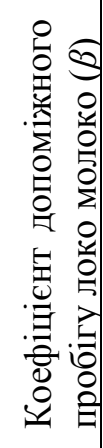 & 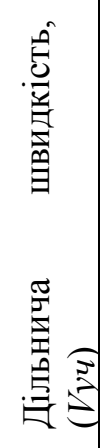 & 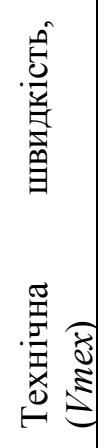 & 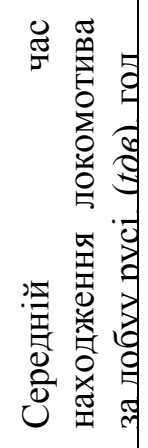 & 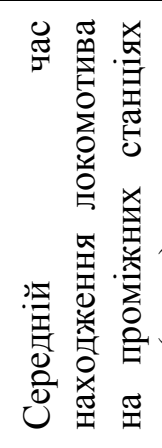 & 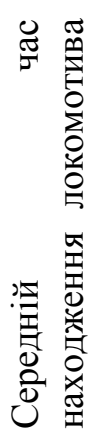 & 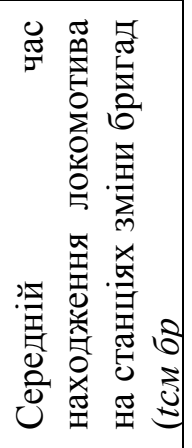 \\
\hline & 198 & & 2072 & 55,5 & 496,8 & 6 & 32,2 & 45,3 & 11,5 & $1, \mathrm{~J}$ & כ, & \\
\hline 2014 & 1446482 & 3437 & 2099 & 55,5 & 500,8 & 0,16 & 39,5 & 45,0 & 11,02 & 1,0 & , & 0,7 \\
\hline
\end{tabular}

Найвищий (1 рівень) складає показник продуктивності локомотива $\left(E_{l}\right)$, що інтегрує всі показники нижчих рівнів та $є$ комплексним показником використання локомотивного парку [2]

$$
E_{л}=Q_{\sigma p} S_{л}(1-\beta),
$$
брутто, $m$;

де $Q_{\sigma p}-$ середня вага вантажного поїзда

$S_{л} \quad-$ середньодобовий пробіг локомотива, км; локомотива.

$\beta$ - коефіцієнт допоміжного пробігу

Визначаємо ступінь впливу кожного показника окремо. Вплив середньої ваги поїзда на продуктивність локомотива становить:

$$
\Delta E_{л}\left(\text { вiд } Q_{\sigma p}\right)=S_{л}^{13}\left(Q_{\sigma p .}^{14}-Q_{\sigma p}^{13}\right)\left(1-\beta^{13}\right)=496,8(3437-3423)(1-0,16)=5842 \text { ткм брутто, }
$$

Тобто за рахунок збільшення ваги поїзда на $14 m$ у 2014 р. відбулося зростання середньодобової продуктивності локомотива на

Вплив середньодобового пробігу локомотива на продуктивність локомотива 5842 ткм брутто.

$$
\Delta E_{n}\left(\text { вiд } S_{n}\right)=\left(S_{n}^{14}-S_{n}^{13}\right) Q_{\sigma p}^{13}\left(1-\beta^{13}\right)=(500,8-496,8) \cdot 3423(1-0,16)=11501 \text { ткм брутто. }
$$

Зважаючи на те, що у базовому i звітному розрахунок їx впливу на продуктивність періодах коефіцієнти допоміжного пробігу локомотива здійснювати недоцільно.

локомотива рівні за їх значеннями $(0,16)$,

3 проведених розрахунків випливає, що:

$$
\Delta E_{л \text { розрах }}=\Delta E_{л}\left(\text { від } Q_{\text {бр }}\right)+\Delta E_{л}\left(\text { від } S_{л}\right)=5842+11501=17342 \text { ткм брутто. }
$$

У нашому випадку існує непогодженість звітних і розрахункових даних

$$
\Delta E_{л \text { звіт }}-\Delta E_{л \text { розр. }}=23284-17342=5942 \text { ткм брутто. }
$$

Визначаємо коефіцієнт невідповідності звітних і розрахункових даних

$$
K_{H}=23284: 17342=1,343 .
$$


Корегуємо вплив кожного показника на середньодобову продуктивність локомотива

$\Delta E_{\text {л розрах. }}=5842 \cdot 1,343+11501 \cdot 1,343=$

$=23284$ ткм брутто.

Величина середньої ваги поїзда брутто $\left(Q_{б p}\right)$, у свою чергу, залежить від середньої ваги поїзда нетто $\left(Q_{m m}\right)$ і ваги тари рухомого складу $\left(Q_{m}\right)$.

Зв'язок цих показників математично записується так:

$$
Q_{\sigma p .}=Q_{\mu m}+Q_{m} \text {. }
$$
окремо.

Визначаємо вплив кожного показника

Вплив середньої ваги поїзда нетто на середню вагу поїзда брутто становить:

$$
\Delta Q_{\sigma p}\left(\text { вi } Q_{m}\right)=Q_{н m}^{14}-Q_{н m}^{13}=2099-2072=27 m \text {. }
$$

Вплив середньої тари рухомого складу на середню вагу поїзда нетто дорівнює

$$
\begin{gathered}
\Delta Q_{\text {бр }}\left(\text { від } Q_{m}\right)=Q_{m}^{14}-Q_{m}^{13}=1338-1351=-13 m ; \\
\Delta Q_{б р}=27-13=14 \mathrm{~m} .
\end{gathered}
$$

Величина середньої ваги поїзда нетто $Q_{\text {нm }}$, у свою чергу, залежить від двох показників: динамічного навантаження робочого парку $P_{\partial p} \mathrm{i}$ кількості вагонів у складі $m$.

Математично ця залежність записується так:

$$
Q_{н m}=P_{\partial p} \cdot m \text {. }
$$

Зважаючи на те, що середня кількість вагонів у складі вантажного поїзда у 2013 та 2014 років була рівною (55,5 вагонів), вплив на середню вагу поїзда нетто здійснювався тільки через динамічне навантаження робочого парку вагонів. Аналогічні розрахунки здійснюється по всіх ієрархічних рівнях.

Висновок. Удосконалення методики оцінки ефективності експлуатації локомотивного парку сприяють забезпеченню отримання об'єктивних результатів щодо використання магістральних локомотивів. Це дозволить здійснювати більш високий контроль і вплив на результати експлуатаційної діяльності залізниць.

\section{СПИСОК ЛІТЕРАТУРИ}

1. Довідник основних показників роботи залізниць України / За ред. Н.В. Котіль. - Київ: ТОВ «Девалта», 2015. - 60 с.
2. Ейтутіс Г.Д. Матричний підхід щодо впливу якісних показників на ефективність використання рухомого складу / Г.Д. Ейтутіс, В.В. Габа // Збірник наукових праць (ДЕТУТ, серія «Економіка і управління», 2015. - Вип. 33, C. 91-103).

3. Ейтутіс Г.Д. Міжнародний вимір продуктивності і залізничного транспорту України як основа вибору напрямів його модернізації / .Д. Ейтутіс, В.М. Карпов, О.I. Никифорук // Економіст. - 2014. - №5. - с.63-68.

4. Кулаєв Ю.Ф. Економіка залізничного транспорту: Навчальний посібник / Ю.Ф. Кулаєв. - 2-е вид., переробл. і доповн., К.: Фенікс, 2012. $240 \mathrm{c}$.

5. Лунина Т.А., Измерение эффективности производственных бизнес процессов инфраструктурного комплекса /Лунина Т.А., Прудников А.А. // Экономика железных дорог. - 2015. - № 6. с. 22-30.

6. Макаренко М.В. Основи управління економічними процесами на залізничному транспорті України: Монографія. - К.: КУЕТТ, 2003. - 478 с.: іл.: Бібліограф.

7. Пасічник B.I. Управління економікою експлуатаційної роботи залізниць України: навч. посібник для вузів / В.І. Пасічник. - К.: Основа, 2005.- 372 c.

8. Транспортний маркетинг: ученик / В.Г. Галабурда, Г.В. Бубкова, Е.А. Шакова и др.; под. Ред. В.Г. Галабурды. - Изд. перераб. и док. М.: ФГОУ «Учебно-методический центр по образованию на железном транспорте», 2011. $452 \mathrm{c}$.

9. Мачерет Д.А. Долгосрочные изменения веса и скорости грузовых поездов и их экономическое значение / Д.А. Мачерет // Железнодорожный транспорт. - 2014. - № 6. - С. $52-55$.

10. Parmenter D. Key Performance Indicatorc - developing, implementing and using winning KPIs / D.Parmenter. - jon Wiley \& sons, 2007. -320 p.

11. Pierantonio Di L. The Economics of EU Railway Reform / L. Di Pierantonio, j. Pekamans // Bruges European Economic Policy Brifing - 2008 № $8-38 \mathrm{p}$.

Рецензент д.е.н., професор ДЕТУТ Ейтутіс Г.Д. Експерт редакційної колегії к.е.н., дочент УкрДУЗТ Слагін Ю.В. 